\title{
SOCIAL ENTREPRENEURSHIP: SUPPORT FOR SOCIAL ENTERPRISES IN BULGARIA
}

\author{
Venelin Terziev ${ }^{1}$ and Marin Georgiev ${ }^{2}$ \\ ${ }^{1}$ Academician of the Russian Academy of Natural History, Moscow, Russia, \\ Prof. D.Sc. (Ec.), D.Sc. (National Security), D.Sc. (Social Activities), Ph.D., National Military \\ University, Veliko Tarnovo, Bulgaria; University of Rousse, Rousse, Bulgaria, terziev@skmat.com \\ ${ }^{2}$ Ph.D., National Military University, Veliko Tarnovo, Bulgaria, clementon@abv.bg
}

\begin{abstract}
Social entrepreneurship is identified at European Union (EU) as a key instrument for regional cohesion and overcoming the problems of poverty and social exclusion. As part of its policy to promote the social economy and social innovation, social entrepreneurship contribute to achieving the strategic goals set in 2020 .

Legally binding definition for social enterprise at EU level has not been introduced. However, in the last 5 years we have seen that the leading strategic and normative documents define uniformly key elements in the definition.
\end{abstract}

Keywords: social entrepreneurship, support, social enterprises.

\section{INTRODUCTION}

One of the advantages of the social economy is a sufficiency of material re-sources enjoyed by sources and reserves to which the state has no access. Mobiliza-tion of movable and immovable property which is personal property of volunteers in the process is a prerequisite for market flexibility. As a result, this avoids the heavy bureaucracy, political relationships, financial rivalries is able to fail even ventures a national priority and above all it saves time.

Notwithstanding the phenomenal potential of self logistical provision, social policy of the state should not omit from sight your material needs of the social econ-omy and the opportunity to promptly allocate such funds, which could prove crucial especially for preservation and development of employment especially in times of crisis. As a rule, social and economic impact of the addition of one such resource is very large.

\section{SUPPORT FOR SOCIAL ENTERPRISES}

Like the material and the provision of financial resources on the subjects of social economy generally is provided voluntarily by the participants, which provides security and flexibility due to the absence of bureaucratic obstacles. A serious problem with self-financing is scarce potential.

In this aspect, the social policy of the state suggests various approaches for financial support for the sector through: 
- Schemes to provide grants for the creation and development of social enterprises and social platforms;

- Tax relief - extending the current preferences for all social enterprises under strict control of the nature of activities of social enterprises;

- New tax incentives for social enterprises;

- Government subsidies eligible under Regulation block off certain state aid;

- Access to credit;

- Identification of additional specific criteria for businesses of social economy in their participation in the procedures for obtaining public contracts, since by their nature they are not equivalent to capital associations;

- Promotion of philanthropy in favor of the social economy through tax incentives for donors;

- Seeking opportunities to use the programming period 2014-2020 for planning and funding for the implementation of national and local policies.

Significant addition of this resource possible Operational Programme „Human Resources Development“ and OP "Competitiveness" for the periods 2007-2013 and 2014-2020, in particular the OP „HRD“:

- Priority 5 „Social inclusion and promotion of social economy“:

Priority 5.1. Support the social economy. The aim is to stimulate initiatives in the social economy and investment in social capital by supporting the development of social entrepreneurship as an opportunity to improve the quality of life of individuals at risk and overcoming social isolation. Forthcoming opening of two new operations - „New Opportunities“ - this operation aims to support the development process of social economy and create social capital by supporting municipalities to provide employment and activity of persons at risk; "Chance for All“ - the scheme aims to support the social inclusion of people with disabilities by supporting specialized enterprises and cooperatives of people with disabilities to provide training to acquire or enhance their professional qualifications and employment for people with disabilities.

Priority 5.2. Social services for prevention of social exclusion and overcoming its consequences. The aim is to expand the opportunities for improving the quality of life of vulnerable groups and / or their families by promoting equal opportunities for vulnerable groups and expand the volume, diversity and targeting of social services in the community and in institutions.

- Priority 1 „Promotion of economic activity and the development of labor market inclusive“:

Priority 1.1. „Integration of vulnerable groups in the labor market“, „Operation Training and adaptation“ aimed at re-socialization of persons serving a penalty of imprisonment.

Resources that determine the development of the social economy and its components have different functions and effect. Political resource appears as a generalization and a regulator of other resources and financial determines their physical activity.

At the central government level

The state monitors the status and development of the social economy and through its competent institutions and experts, primarily through existing social protection systems, supports the entities in the social economy to maintain their capacity and territorial coverage adequate to the level of unemployment and social exclusion.

Presumably the resources of the entities in the social economy are secured separately by using personal material, financial and labor contributions of the participants in the activities. Depending on the current or prospective social and political reasons, the government granted to certain entities in the social economy target: human resources (through recruitment, through education and training measures); material resources, which also includes the provision of premises and communal services; financial resources.

Since the financial resource is able to replace or generate other resources, the European Commission and national governments adopt a particular view regarding the allocation of funds for social economy for the following reasons:

- Amount of such subsidy is very small in scale compared to national budgets;

- Returns as a specific product and stabilizing effect is usually very high; 
- Moral and mobilizing effect is high and essentially irreplaceable.

The Regulation on block off "de minimis" allows member states to grant up to $€ 200,000$ of certain companies, including acting in the social economy, without any formalities. In 2008, the Commission adopted the General Regulation Block Off ((EU) № 800/2008), allowing Member States to grant a large number of categories of aid (training, employment, SMEs, environmental protection and others) without prior notification to the Commission. In the context of the financial crisis, the Commission adopted a temporary framework allowing Member States to grant additional assistance in order to ensure access to finance. All these categories of aid can be particularly useful for social enterprises and can be obtained without or with very little red tape.

The state pursues a consistent social policy appropriate to the nature of the social economy and force her subjects aimed at stabilizing the social outcomes they achieve, which will introduce procedural, tax, and people with disabilities and infrastructure concessions.

On local level

The competent state body charged with the implementation of the National concept of social economy, implement the state policy in the field of social economy on a territorial basis through the national network of executive agencies and local government.

At the level of social dialogue - recognition as a social partner

The social economy as an element of social dialogue is a concept understandable and acceptable by existing social partners to the subject of social dialogue and opportunities of social economy gives the example of resolving social contradictions account functioning both as an employer, employee, investor and owner of businesses.

At European level, the European Centre of Enterprises with Public Participation and of Enterprises of General Economic Interest (CEEP) is recognized by the European Commission representative association of employers in the European social dialogue. As a social partner, CEEP represents the interests of its members, which include social enterprises to European institutions consulted by the European Commission on the draft legislation. CEEP delegate their representatives and observers in committees and advisory bodies of the European institutions and so is able to protect the interests of its members.

Based on the principle of subsidiarity, Member States may apply this model to the national social dialogue. The European Parliament (A6-0015 / 2009) supports the need to recognize the components of the social economy in the European sectoral and cross-sectoral social dialogue and requires both the Commission and Member States to encourage the process of inclusion of existing entities of the social economy in tripartite advice on all employment law and insurance issues.

The social economy sector is developing thanks to trained personnel. In this regard was adopted and the European Parliament Resolution of 20 May 2010 on a new partnership for the modernization of universities for dialogue between universities and business, in which the EP:

- 46. Reiterates that commercial entrepreneurship in its various forms should be regarded as one of the possible professions for young graduates and the need for higher education institutions to provide students with detailed knowledge of all forms of entrepreneurship, including social and solidarity economy, encouraging them, for instance, to establish their own companies;

- 72. It encourages the Commission to continue promoting dialogue at national, local and regional level with a focus on best practices and to ensure that such dialogue involves all interested parties (eg. Social partners) and all types of enterprise (SMEs, social and solidarity economy, etc.), as well as representatives of third countries (NGOs, etc.) with a view to highlighting the economic and social added value of cooperation between the two worlds of university and business.

Attitudes and reactions of the academic and research community in Bulgaria have adequate time and essentially a standing agenda Bulgaria need to fit into this as-pect of the process of European social inclusion.

Training in Social Entrepreneurship is one of the best innovations in higher ed-ucation. But existing occupations does not currently reflect the extent necessary, the specific nature and content of social entrepreneurship. Discussed is the need to be regulated the profession of the social entrepreneur (Terziyev, 2019; Terziev, Bencheva, 2019a; Bencheva, Stoeva, Todorova, 2018; Bencheva, Tepavicharova, 2016; Tepavicharova, Bencheva, 2016a; Bogdanova, 2018a; Terziev, 2019b-c; Terziev, Bekiarova, Georgiev, 2019d; Bencheva, Stoeva, 2019e; Stoeva, 2016b-c; Arabska, 2016d). 


\section{TRAINING IN SOCIAL ENTREPRENEURSHIP}

Training in social entrepreneurship are available in varying degrees in the formal education system according to curricula developed for different levels and educational levels - primary, primary, secondary, vocational and tertiary education. Vocational training centers, vocational colleges and organizations operating in the field of trainings provide much greater options and flexibility by conducting informal training (Petkova, 2008, Petkova, 2009; Petkova - Georgieva, Yanakieva, 2012; Petkova, Strateva, 2012a; Petkova, Tasheva, Petkov, 2018b-c).

Priorities of the National Strategy for lifelong learning are :

- A step towards a new educational approach and innovation in education and training;

- Improving the quality of education and training;

- Provide educational environment for equal access to lifelong learning for active social inclusion and active citizenship;

- Promotion of education and training to meet the needs of the economy and changes in the labor market;

All areas of impact support the acquisition and continued development of nine key competences for lifelong learning in a single process: competences in Bulgarian language; communication skills in foreign languages; mathematical competence and basic competences in science and technology; digital competence; learning skills; social and civic competences; initiative and entrepreneurship; cultural awareness and expression through creativity; skills to support sustainability and a healthy lifestyle (Ovcharova, 2017-a).

\section{CONCLUSION}

Although in a number of programmatic and strategic documents related to training and education, talk about the importance of entrepreneurship, the extraction of data provided opportunities is very difficult, not to mention the reporting of results.

But the fact is that more and more projects and programs oriented towards entrepreneurship, in particular social entrepreneurship as a particular focus and include a mandatory training component of the target groups - eg. Program for Social Entrepreneurship of the non-profit organization Bulgarian Center for Nonprofit Law. The training offered by consulting firms will develop in the future, but very often they are just used to attract customers (Terziev, Nichev, Georgiev, 2019f-g).

This report provides an analysis of the development of social entrepreneurship in Bulgaria according to: International project Social enterprise skills for business advisors - SESBA of the European program for education, training, youth and sport "Erasmus +", Grant Agreement №2015-1-EL01-KA202-014097 (20152018).

\section{REFERENCE LIST}

Terziyev, Venelin. (2019). Sotsial'naya ekonomika i sotsial'noye predprinimatel'stvo. // Sovremennyy menedzhment: problemy i perspektivy: sbornik statey po itogam XIV mezhdunarodnoy nauchnoprakticheskoy konferentsii „Sovremennyy menedzhment: problemy i perspektivy“ 25-26 aprelya 2019 goda, Ministerstvo nauki i vysshego obrazovaniya Rossiyskoy federatsii, Izdatelstvo SanktPeterburgskogo gosudarstvennogo ekonomicheskogo universiteta, Sankt-Peterburg, Rossiya, 2019, s. 412-435, ISBN 978-5-7310-4567-4 (Терзиев, Венелин. Социальная экономика и социальное предпринимательство. // Современный менеджмент: проблемы и перспективы: сборник статей по итогам XIV международной научно-практической конференции „Современный менеджмент: проблемы и перспективы“ 25-26 апреля 2019 года, Министерство науки и высшего образования Российской фредерации, Издательство Санкт-Петербургского государственного экономического университета, Санкт-Петербург, Россия, 2019, с. 412-435, ISBN 978-5-7310-4567-4).

Terziev, V, Bencheva, N. (2019a). Current status of social entrepreneurship in Bulgaria. // Advances in Bulgarian science'2018, National centre for information and documentation (NACID), Sofia, 2019, pp.5-18, ISSN 1314-3565.

Bencheva, N., Stoeva, T., Todorova, S. (2018). Key Skills and Competences for Social Business Advisors: Views from Experts, International Journal of Organizational Leadership, 7(2018), pp.413-425; ISSN 2383-1103 (Print); ISSN 2345-6744 (Online). 
IJASOS- International E-Journal of Advances in Social Sciences, Vol. V, Issue 14, August 2019

Bencheva, N., Tepavicharova, M. (2016). Support structures for social entrepreneurship in Bulgaria, The first scientific conference on social entrepreneurship on "Tips, skills and tools for consulting social entrepreneurs", pp.29-35, ISBN 978-954-517-249-6 ISBN 978-954-517-250-2.

Petkova, St., (2008). Balanced scorecard as instrument of strategic controlling, Forum Gesundheit und Soziales, Beitrage aus Lehre, Forschung und Praxis der Studiengange der Evangelischen Fachhochschule Berlin, Heft 6, p.60-68, ISSN 1863-1851, Berlin, 2008.

Petkova, St. (2009). Tendentsii za upravlyavane na strategicheskiya risk s pomoshtta na balansirani sistemi ot pokazateli, Godishnik na MGU „Sveti Ivan Rilski”, tom 52, str.87-91, ISSN 1312-1820, Sofiya, 2009 (Петкова, Ст., Тенденции за управляване на стратегическия риск с помощта на балансирани системи от показатели, Годишник на МГУ „Свети Иван Рилски”, том 52, стр.87-91, ISSN 13121820, София, 2009).

Petkova - Georgieva, St., A., Yanakieva, (2012). Balansiranata sistema ot pokazateli kato savremenen metod na upravlenie $v$ turisticheskoto predpriyatie, akademichno spisanie "Upravlenie i obrazovanie", tom VIII, kn. 1, str.140-144, ISSN 13126121, Burgas, 2012. (Петкова - Георгиева, Ст., А., Янакиева, Балансираната система от показатели като съвременен метод на управление в туристическото предприятие, академично списание "Управление и образование", том VIII, кН. 1, стр.140-144, ISSN 13126121, Бургас, 2012).

Petkova, St., Iv. Strateva, (2012a). Opredelyaneto na strategicheskite vrazki po deynosti kato klyuchov podhod v kontrolinga, godishnik na Universitet "Prof. d-r Asen Zlatarov", Br. XLI, kn. 2, str.106-112, ISSN 1312-1359, Burgas, 2012 (Петкова, Ст., Ив. Стратева, Определянето на стратегическите връзки по дейности като ключов подход в контролинга, годишник на Университет “Проф. д-р Асен Златаров", Бр. XLI, кн. 2, стр.106-112, ISSN 1312-1359, Бургас, 2012).

Tepavicharova, M., Bencheva, N. (2016a), Factors for development of the educational and professional qualitication profile of the managers from the services sector in Bulgaria, Scientific journal «Economics and Finance», Science and Practice, Conference proceedings, Citation Index - Social Sciences \& Humanities (CPCI-SSH), Thorpe-Bowker, Melbourne, Australia, pp.42-47, ISBN 978-0-9942661-3-2.

Bogdanova, Margarita. (2018a). Policies and Instruments for Social Development. Journal of Innovations and Sustainability, Plovdiv, Bulgaria, 4, 2018, 1, pp. 59-63, ISSN 2367-8127 (CD-ROM), ISSN 23678151 (ON-LINE).

Petkova, S., Tasheva, Y., P. Petkov, (2018b). Assessment of the Pyrolytic Fractions from Refused - Derived Fuel, Oxidation Communications, p. 462 - 467, book 41, vol. 3, ISSN 0209-4541, 2018.

Petkova, S., Tasheva, Y., P. Petkov, (2018c). Evaluation of Possibility to Use Liquid Pyrolysis Fractions as Fuel, Oxidation Communications, p. 468 - 474, book 41, vol. 3, ISSN 0209-4541, 2018.

Terziev, Venelin. (2019b). Social policy and labor market development in Bulgarian transition period. INTCESS 2019- 6th International Conference on Education and Social Sciences, 4-6 February, 2019, Dubai, International Organization Center of Academic Research, 2019, pp. 703-714, ISBN: 978-60582433-5-4.

Terziev, Venelin. (2019c). Theoretical basis of development of labor market and social policy in the republic of Bulgaria. INTCESS 2019- 6th International Conference on Education and Social Sciences, 4-6 February, 2019, Dubai, International Organization Center of Academic Research, 2019, pp. 715-726, ISBN: 978-605-82433-5-4.

Terziev, V., Bekiarova, N., Georgiev, M. (2019d). Support structures for the development of social entrepreneurship. // KNOWLEDGE - Capital of the future, International Journal Scientific Papers Vol. 29.1, February, 2019, Institute of knowledge management - Skopje, Macedonia, 29, 2019, N 1, pp. 21-25, ISSN 1857-923X (for e-version), ISSN 2545 - 4439 (for printed version).

Bencheva, N., Stoeva, T. (2019e). The role of management skills in social entrepreneurship: expert assessment. // 20th International conference - Knowledge without borders, Vrnjacka Banja, Serbia (29-31.03.2019), Institute of knowledge management - Skopje, Macedonia, 30, 2019, N 6, pp. 15931597, ISSN 1857-923X (for e-version), ISSN 2545 - 4439 (for printed version).

Stoeva, Teodora. (2016b). Predizvikatelstva i potrebnosti ot obucheniya na sotsialnite biznes konsultanti. // Parva nauchna konferentsiya po sotsialno predpriemachestvo. Saveti, umeniya i instrumenti za konsultirane na sotsialnite predpriemachi. Agraren Universitet Plovdiv, 2016, str. 71-74 (Стоева, Теодора. Предизвикателства и потребности от обучения на социалните бизнес консултанти. // 
Първа научна конференция по социално предприемачество. Съвети, умения и инструменти за консултиране на социалните предприемачи. Аграрен Университет Пловдив, 2016, стр. 71-74).

Stoeva, Teodora. (2016c). Sotsialni deynosti v obshtina Plovdiv. // Parva nauchna konferentsiya po sotsialno predpriemachestvo. Saveti, umeniya i instrumenti za konsultirane na sotsialnite predpriemachi. Agraren Universitet Plovdiv, 2016, str. 111-117 (Стоева, Теодора. Социални дейности в община Пловдив. // Първа научна конференция по социално предприемачество. Съвети, умения и инструменти за консултиране на социалните предприемачи. Аграрен Университет Пловдив, 2016, стр. 111-117).

Arabska, Ekaterina.(2016d). Iziskvaniya za umeniya ot konsultantite za osiguryavane na efektivna podkrepa na sotsialnite predpriyatiya. // Parva nauchna konferentsiya po sotsialno predpriemachestvo. Saveti, umeniya i instrumenti za konsultirane na sotsialnite predpriemachi. Agraren Universitet Plovdiv, 2016, str. 75-81 (Арабска, Екатерина. Изисквания за умения от консултантите за осигуряване на ефрективна подкрепа на социалните предприятия. // Първа научна конфреренция по социално предприемачество. Съвети, умения и инструменти за консултиране на социалните предприемачи. Аграрен университет Пловдив, 2016, стр. 75-81).

Ovcharova, S. (2017). Motivation in knowledge economy. // $6^{\text {th }}$ International congress Knowledge Economy \& Management, 26-28.12.2007, Istanbul, Turkey, 2017, pp.1643-1651. ISSN: 1308-3937.

Ovcharova, S. (2017a). Knowledge management in some Bulgarian organizations. // 6th International congress Knowledge Economy \& Management, 26-28. 12.2007, Istanbul, Turkey, 2017, pp.19081915. ISSN 1308-3937.

Terziev, V., Nichev, N., Georgiev, M. (2019f). Current status of social entrepreneurship: social enterprises and state. $/ / 20^{\text {th }}$ International conference - Knowledge without borders, Vrnjacka Banja, Serbia (2931.03.2019), Institute of knowledge management - Skopje, Macedonia, 30, 2019, N 6, pp. 1587-1591, ISSN 1857-923X (for e-version), ISSN 2545 - 4439 (for printed version).

Terziev, V., Nichev, N., Georgiev, M. (2019g). Social enterprises and their impact in Bulgaria. // $20^{\text {th }}$ International conference - Knowledge without borders, Vrnjacka Banja, Serbia (29-31.03.2019), Institute of knowledge management - Skopje, Macedonia, 30, 2019, N 6, pp. 1645-1649, ISSN 1857923X (for e-version), ISSN 2545 - 4439 (for printed version). 